\title{
Lack of Knowledge: Breast Cancer and the Soluble Interleukin-6 Receptor
}

\author{
Heike Knüpfer Rainer Preiss \\ Institute of Clinical Pharmacology, University of Leipzig, Germany
}

Key Words

slL-6R · IL-6 · Breast cancer · Transsignaling

\section{Summary}

Background: Cytokines are and may be used as therapeutic targets in cancer therapy. In breast cancer, interleukin (IL)- 6 is associated with different features of tumor biology like metastasis, certain stages, and decreased survival. It is now an established fact that signaling via the soluble IL-6 receptor (sIL-6R) ('transsignaling') is an important process in the IL- 6 machinery. Methods and Results: In this mini-review, we discover that published knowledge about sIL-6R serum levels in breast cancer patients is sparse and, furthermore, most in vitro data merely show that tumor cells produce the sIL-6R endogenously. Conclusions: Therefore, a lot of research is still necessary to analyze the significance of the sIL-6R and therefore the transsignaling process in breast tumors. More knowledge about the sIL-6R in breast cancer would give insights into its putative role as blood marker of active tumor disease. Secondly, the sIL-6R may be useful in breast cancer as a new therapeutic pathway. If, as suggested by the literature, IL- 6 mediates the aggressiveness and the growth of breast tumors, elevated circulating levels of IL- 6 and its receptor may identify patients for whom the IL-6 complex is a therapeutic target.

\section{General Remarks on Breast Cancer}

Worldwide, breast cancer is one of the most frequent and deadly cancers. Although the survival of patients has increased over the last decades in relation with screening programs and post-operative adjuvant systemic therapies, many

\author{
Schlüsselwörter \\ sIL-6R · IL-6 · Mammakarzinom · Transsignaling
}

\section{Zusammenfassung}

Hintergrund: In der Krebstherapie stellen Zytokine therapeutische Angriffsziele, sogenannte Targets, dar. Beim Mammakarzinom ist ein hoher Interleukin (IL)-6-Gehalt mit verschiedenen Tumorcharakteristika wie z.B. Metastasierung, bestimmten Stadien und vermindertem Überleben assoziiert. In der Zwischenzeit hat sich herausgestellt, dass die Signalweiterleitung über den löslichen IL6-Rezeptor (sIL-6R) («Transsignaling») von großer Bedeutung innerhalb des IL-6-Geschehens ist. Methoden und Ergebnisse: In diesem Mini-Review stellen wir fest, dass das publizierte Wissen über den Serumgehalt an sIL-6R bei Mammakarzinompatienten lückenhaft ist. Des Weiteren zeigen publizierte In-vitro-Daten lediglich die Tatsache, dass Tumorzellen selber den sIL-6R produzieren. Schlussfolgerungen: Aus diesem Grunde erscheint es uns notwendig herauszufinden, welche Bedeutung der sIL-6R, und damit einhergehend der TranssignalingProzess, beim Mammakarzinom hat. Ein breiteres Wissen über den sIL-6R beim Brustkrebs könnte seine Rolle als eventueller Marker des aktiven Tumorgeschehens beleuchten und eine neue therapeutische Möglichkeit darstellen, zumindest für diejenigen Patienten, deren Serumgehalte an IL-6 und/oder sIL-6R erhöht sind.

patients die from metastatic relapse. Therefore, breast cancer is still a challenge for clinicians and researchers. In the last years, a lot of research was done to identify prognostic markers. One example is the immunologically important cytokine interleukin (IL)-6 and the corresponding IL-6 signaling system.

\begin{tabular}{ll}
\hline KARGER & @ 2010 S. Karger GmbH, Freiburg \\
Fax +497614520714 & Accessible online at: \\
Information@Karger.de & www.karger.com/brc \\
www.karger.com &
\end{tabular}




\section{Significance of Serum IL-6 in Breast Cancer Patients}

A role for IL-6 in neoplastic disease is suggested by the observation that circulating levels of the cytokine increase markedly during development and progression of breast and other tumors. Reviewing the literature, we recently were able to show that the published data are surprisingly unique, indicating high serum IL-6 levels to be a negative prognostic factor in breast cancer patients [1].

\section{Prerequisite for IL-6 Signaling}

IL-6 has a dedicated receptor that can be found either on the cell membrane or in a solubilized form $[2,3]$. The receptor binds IL-6 in the circulation system as well as on the cellular membrane. Genes encoding the IL-6 receptor (IL-6R) were located on chromosomes 1 and 9 [4]. Later, it was shown that the gene located on chromosome 9 was a pseudogene, and Kluck et al. [5] demonstrated that the gene on chromosome $1 \mathrm{p} 21$ corresponded to the active gene.

The receptor complex binds to the gp130 transmembrane receptor $[2,6]$. Subsequently Jak2 is activated, which in turn activates multiple pathways, with the STAT3 pathway being described in most detail [6]. STAT factors (STAT = signal transducer and activator of transcription) participate in the transcriptional regulation of genes comprising STAT-specific binding sites. gp130 is expressed by all cells in the body, whereas the IL-6R is mainly expressed by hepatocytes, neutrophils, monocytes/macrophages, and some lymphocytes. In addition to the cellular gp130, a second soluble form of gp130 (sgp130) exist, which is described as an antagonist to IL-6 [7].

The soluble IL-6R (sIL-6R) together with IL-6 stimulates cells that only express gp130 [8-10], a process named transsignaling (fig. 1). This process implicates that cells that were originally unresponsive to IL-6 (because of the lack of membrane-bound IL-6R) become now responsive via the soluble sIL-6R/IL-6 complex. Embryonic stem cells [11], early hematopoietic progenitor cells [12], T cells [13], many neural cells [14], smooth muscle cells [15], and endothelial cells [16] are responsive to IL- 6 only in the presence of sIL-6R.

\section{Significance of Transsignaling via sIL-6R}

It has only been within the last few years that the full impact of IL-6 transsignaling has begun to be appreciated. The importance of the sIL-6R is underlined by the fact that about $70 \%$ of the secreted IL- 6 forms a complex with the sIL-6R in the blood and binds directly to membrane gp130 [17]. The other $30 \%$ has only a transient existence in the blood, or binds to the membrane-bound receptor (mIL-6R) [17, 18]. The study of Peters et al. [19] clearly shows in transgenic mice that

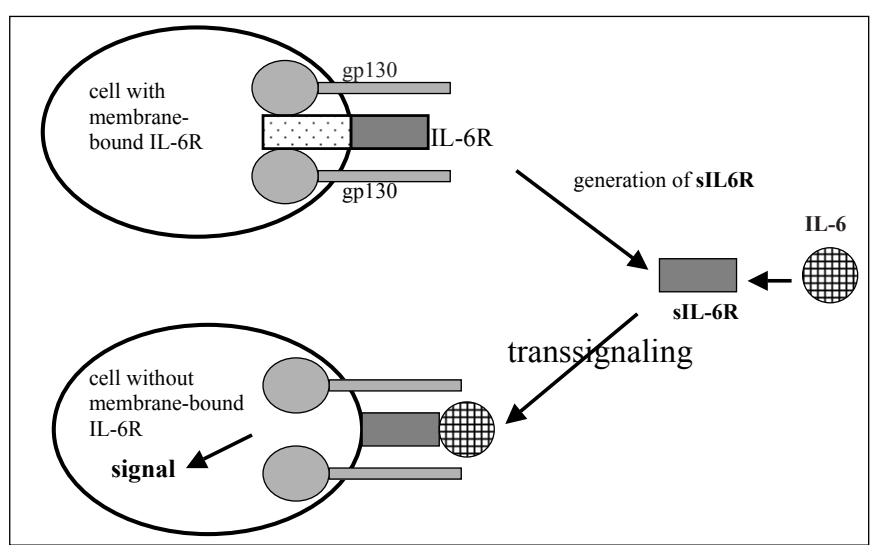

Fig. 1. The transsignaling process via generation of the sIL-6R. The transsignaling process is dependent on the membrane-bound gp130.

the sIL-6R functions as a carrier protein for its ligand, thereby markedly prolonging the plasma half-life of IL-6, indicating that IL-6 signaling is increased by the sIL-6R. The significance of the sIL-6R is further underlined by a study done by Vermes et al. [20] analyzing human osteoblasts. They found osteoblasts to express cell surface IL-6R, but the membrane-bound IL-6R was unable to transmit IL-6-induced signals (tyrosine phosphorylation of gp130 is an essential step in the IL-6-induced signaling mechanism) until it is shed in its soluble form, the sIL-6R. The results of Modur et al. [21] show that, for the IL-6 signaling process, the limiting factor is the sIL-6R, not the cytokine IL-6. Endothelial cell activation depended on the concentration of the sIL-6R. The study of Becker et al. [13] using a colon tumor mouse model shows that IL-6 signal transduction was mediated by the soluble rather than the membrane-bound IL-6R, indicating that tumor growth is controlled by IL- 6 transsignaling via the soluble form of the IL-6R.

Taking into consideration that IL-6 is an important factor in cancer biology and may be used as a novel prognostic factor at least in breast cancer, one can speculate that the soluble receptor, and therefore the signaling process, may also have important tumor-promoting capacities.

\section{Serum Levels of sIL-6R in Cancer}

Many publications deal with the elevated IL-6 serum levels in different cancer types. In regard to the soluble IL-6R, there is considerably less information about the significance of serum IL-6R levels in cancer patients, especially in breast cancer.

\section{Serum Levels of sIL-6R in Different Cancer Types}

Regarding the literature, elevated and non-elevated sIL-6R values in cancer patients are published. Andrews et al. [22], analyzing patients with carcinomas of the bladder, found high 
levels of sIL-6R to be associated with pathological tumor grade. Similar results were found for patients with prostate cancer [23]. Perioperative sIL-6R levels were significantly associated with tumor volume and metastases to lymph nodes. In 46 untreated multiple myeloma (MM) patients, the sIL-6R levels were significantly elevated in comparison to controls and were significantly higher in stage III disease in comparison to stages I and II [24]. Similar results with MM patients were achieved by Stasi et al. [25]. Concerning patients with B cell chronic lympocytic leukaemia (B-CLL), the concentration of sIL-6R was significantly higher in untreated and treated patients when compared to healthy persons. Furthermore, there was no difference between the sIL-6R levels in patients with complete remission and the healthy controls [26]. The study of Soresi et al. [27], analyzing hepatocellular carcinoma (HCC), showed similar sIL-6R values in all groups and increasing values in stage III HCC patients.

Nevertheless, there are also opposing results. The study of McKeown et al. [28] could not find an elevated plasma level of sIL-6R in non-small-cell lung cancer. In opposite to the study of Alexandrakis et al. [24], Urbanska-Ryes et al. [29] found the serum concentrations of the sIL-6R to be measurable in all MM patients $(\mathrm{n}=121)$ and all healthy controls $(\mathrm{n}=28)$, but the difference between these groups was not significant. Similar results were obtained by Barber et al. [30]. Levels of serum sIL-6R were not significantly different between pancreatic cancer patients and healthy controls. The small patient $(n=13)$ and control numbers $(n=6)$ should, however, be taken into consideration. Analyzing 208 patients with renal cell carcinoma and 25 normal subjects, Alberti et al. [31] did not find any significant difference between the sIL-6R levels of these two populations.

\section{Serum Levels of SIL-6R in Breast Cancer}

The clinical data about the significance of the sIL-6R are scarce. There are three similar studies with only a few patients [32-34]. In a short study, Jablonska and Pietruska [32], analyzing the serum levels of the sIL-6R in controls $(\mathrm{n}=10)$ and breast cancer patients $(\mathrm{n}=15)$, found a trend towards higher serum levels in the patient group (61.2 $\pm 10.2 \mathrm{vs}$. $41.2 \pm 29.9 \mathrm{ng} / \mathrm{ml}$ ), but the difference was not significant. In a second short study, Jablonska [33] analyzed the sIL-6R levels in the culture supernatants of polymorphonuclear (PMN) cells of the peripheral blood and in the serum obtained from breast cancer patients $(n=17)$ and compared them to the sIL$6 \mathrm{R}$ levels of the controls ( $\mathrm{n}=10$, normal healthy women). The mean concentration of the sIL-6R in the culture supernatants of PMN cells from patients was decreased $(0.251 \pm 0.163)$ compared to the controls $(0.396 \pm 0.194 \mathrm{ng} / \mathrm{ml})$, while the level of the sIL-6R in the sera of breast cancer patients was increased compared to the controls $(46.1 \pm 28.7$ vs. $39.05 \pm 19.8 \mathrm{ng} / \mathrm{ml}$, respectively). One should take into consideration that there is no statement of the statistical significance of the difference. Furthermore, no statement was made concerning the prog- nostic value of the sIL-6R. A third study done by Jablonska et al. [34] revealed statistically significant higher serum sIL-6R levels in stage III/IV breast cancer patients $(\mathrm{n}=11 ; 77.7 \pm$ $35.3 \mathrm{ng} / \mathrm{ml})$ compared to controls $(\mathrm{n}=12 ; 41.2 \pm 21.75 \mathrm{ng} / \mathrm{ml})$. The authors concluded that changes in serum values, dependent on clinical progression, could have a diagnostic and prognostic role in cancer disease. Another study done by Kovacs [35], analyzing 76 different cancer patients (breast, gastrointestinal, uterine, ovarian, renal, bladder cancer), found the values of the sIL-6R to be significantly elevated in stage I and II patients, with a 'borderline' significance in stage III and IV $(\mathrm{p}=0.06)$. One should take into consideration that the authors did not discriminate between the tumor types.

To get more precise information about the role of the sIL$6 \mathrm{R}$ in breast tumor patients, a greater number of sera of breast tumor patients has to be screened to confirm the significance of the sIL-6R with regard to prognosis/progression and to make a further clinical contribution to the importance of the IL-6 system in breast cancer.

\section{Significance of sIL-6R in Breast Cancer: In Vitro Results}

Knowledge about the clinical data on the sIL-6R in breast tumor patients is sparse. Concerning laboratory investigations, the situation seems to be similar. The study of Singh et al. [36] shows that breast carcinoma cell lines (MCF-7, T47D, BT20) produce the sIL-6R, but not the cell line MDAMB-231. Addition of $10 \mathrm{ng} / \mathrm{ml}$ IL-6 to MCF-7 cells resulted in an increase in sIL-6R release by $58 \%$. Furthermore, sIL-6R was also present in conditioned medium collected from fibroblasts derived from malignant breast tissue, but not from benign or normal breast tissue-derived fibroblasts. Additionally, the concentrations of sIL-6R were higher in cytosol prepared from malignant breast tissue than in cytosol prepared from normal breast tissue. Oh et al. [37] also showed T47D cells to produce sIL-6R as a splice variant and to secrete soluble IL-6R protein. Recently, our group was also able to show three breast tumor cell lines to endogenously produce sIL-6R (MCF-7, HCC-1143, BT-474) (results submitted for publication).

14 years ago, Novick et al. [38] showed the importance of the sIL-6R in regard to the effects of IL-6 on a breast carcinoma cell line (T47D). They analyzed a purified urinary protein binding IL-6 (IL-6-R-SUP) for its biological activity. They showed that the growth-inhibitory effect of IL-6 on breast carcinoma cells is enhanced by the addition of IL-6-RSUP to these human cells, although they possess abundant IL-6Rs. With IL-6-R-SUP, complete growth inhibition by IL- 6 could be achieved and the cells became more sensitive to low levels of IL-6. These effects were prevented by a monoclonal antibody against IL-6-R-SUP that blocks IL-6 binding to cells. 


\section{Summary}

It is now an established fact that transsignaling is an important process in the IL-6 machinery, but knowledge on the sIL-6R in breast cancer patients is sparse and most in vitro data merely show that tumor cells produce the sIL-6R endogenously.

\section{Conflict of Interest}

The authors declare no conflict of interest.

\section{References}

1 Knüpfer H, Preiss R: Significance of interleukin-6 (IL-6) in breast cancer (review). Breast Cancer Res Treat 2007;102:129-135.

2 Taga T, Kishimoto T: gp130 and the interleukin-6 family of cytokines. Annu Rev Immunol 1997;15: 797-819.

3 Hong DS, Angelo LS, Kurzrock R: Interleukin-6 and its receptor in cancer: implications for translational therapeutics. Cancer 2007;110:1911-1928.

$\checkmark 4$ Szpirer J, Szpirer C, Riviere M, Houart C, Baumann M, Fey GH, Poli V, Cortese R, Islam MQ, Levan G: The interleukin-6-dependent DNA-binding protein gene (transcription factor 5: TCF5) maps to human chromosome 20 and rat chromosome 3 , the IL6 receptor locus (IL6R) to human chromosome 1 and rat chromosome 2, and the rat IL6 gene to rat chromosome 4. Genomics 1991;10:539-546.

5 Kluck PM, Wiegant J, Jansen RP, Bolk MW, Raap AK, Willemze R, Landegent JE: The human interleukin-6 receptor alpha chain gene is localized on chromosome 1 band q21. Hum Genet 1993;90:542544.

6 Hodge DR, Hurt EM, Farrar WL: The role of IL-6 and STAT3 in inflammation and cancer. Eur J Cancer 2005;41:2502-2512.

7 Muller-Newen G, Kuster A, Hemmann U, Keul R, Horsten U, Martens A, Graeve L, Wijdenes J, Heinrich PC: Soluble IL-6 receptor potentiates the antagonistic activity of soluble gp130 on IL-6 responses. J Immunol 1998;161:6347-6355.

$>8$ Taga T, Hibi M, Hirata Y, Yamasaki K, Yasukawa K, Matsuda T, Hirano T, Kishimoto T: Interleukin-6 triggers the association of its receptor with a possible signal transducer, gp130. Cell 1989:58:573-581.

9 Mackiewicz A, Schooltink H, Heinrich PC, RoseJohn S: Complex of soluble human IL-6-receptor/ IL-6 up-regulates expression of acute-phase proteins. J Immunol 1992;149:2021-2027.

10 Rose-John S: Interleukin-6 biology is coordinated by membrane bound and soluble receptors. Acta Biochim Pol 2003;50:603-611.

11 Rose-John S: gp130 stimulation and the maintenance of stem cells. Trends Biotechnol 2002;20:417-419.

12 Peters M, Muller AM, Rose-John S: Interleukin-6 and soluble interleukin-6 receptor: direct stimulation of gp130 and hematopoiesis. Blood 1998;92:3495-3504.

-13 Becker C, Fantini MC, Schramm C, Lehr HA Wirtz S, Nikolaev A, Burg J, Strand S, Kiesslich $\mathrm{R}$, Huber S, Ito $\mathrm{H}$, Nishimoto $\mathrm{N}$, Yoshizaki K, Kishimoto T, Galle PR, Blessing M, Rose-John S, Neurath MF: TGF-beta suppresses tumor progression in colon cancer by inhibition of IL-6 trans-signaling. Immunity 2004;21:491-501.

14 Marz P, Otten U, Rose-John S: Neural activities of IL-6-type cytokines often depend on soluble cytokine receptors. Eur J Neurosci 1999;11:2995-3004.

15 Klouche M, Bhakdi S, Hemmes M, Rose-John S: Novel path to activation of vascular smooth muscle cells: up-regulation of gp130 creates an autocrine activation loop by IL-6 and its soluble receptor. J Immunol 1999;163:4583-4589.
16 Romano M, Sironi M, Toniatti C, Polentarutti N, Fruscella P, Ghezzi P, Faggioni R, Luini W, van Hinsbergh V, Sozzani S, Bussolino F, Poli V, Ciliberto G, Mantovani A: Role of IL-6 and its soluble receptor in induction of chemokines and leukocyte recruitment. Immunity 1997;6:315-325.

17 Gaillard J, Pugniere M, Tresca J, Mani J, Klein B, Brochier J: Interleukin-6 receptor signaling. II. Bio-availability of interleukin-6 in serum. Eur Cytokine Netw 1999;10:337-344.

18 Ndubuisi MI, Patel K, Rayanade RJ, Mittelman A, May LT, Sehgal PB: Distinct classes of chaperoned IL-6 in human blood: differential immunological and biological availability. J Immunol 1998;160:494-501.

19 Peters M, Jacobs S, Ehlers M, Vollmer P, Mullberg J, Wolf E, Brem G, Meyer zum Buschenfelde $\mathrm{KH}$, Rose-John S: The function of the soluble interleukin 6 (IL-6) receptor in vivo: sensitization of human soluble IL-6 receptor transgenic mice towards IL-6 and prolongation of the plasma half-life of IL-6. J Exp Med 1996;183:1399-1406.

20 Vermes C, Jacobs JJ, Zhang J, Firneisz G, Roebuck KA, Glant TT: Shedding of the interleukin-6 (IL-6) receptor (gp80) determines the ability of IL-6 to induce gp130 phosphorylation in human osteoblasts. J Biol Chem 2002;277:16879-16887.

21 Modur V, Li Y, Zimmerman GA, Prescott SM, McIntyre TM: Retrograde inflammatory signaling from neutrophils to endothelial cells by soluble interleukin-6 receptor alpha. J Clin Invest 1997;100: 2752-2756.

22 Andrews B, Shariat SF, Kim JH, Wheeler TM, Slawin KM, Lerner SP: Preoperative plasma levels of interleukin- 6 and its soluble receptor predict disease recurrence and survival of patients with bladder cancer. J Urol 2002;167:1475-1481.

23 Shariat SF, Kattan MW, Traxel E, Andrews B, Zhu K, Wheeler TM, Slawin KM: Association of pre- and postoperative plasma levels of transforming growth factor beta(1) and interleukin 6 and its soluble receptor with prostate cancer progression. Clin Cancer Res 2004;10:1992-1999.

24 Alexandrakis MG, Passam FH, Boula A, Christophoridou A, Aloizos G, Roussou P, Kyriakou DS: Relationship between circulating serum soluble interleukin- 6 receptor and the angiogenic cytokines basic fibroblast growth factor and vascular endothelial growth factor in multiple myeloma. Ann Hematol 2003;82:19-23.

25 Stasi R, Brunetti M, Parma A, Di Giulio C, Terzoli E, Pagano A: The prognostic value of soluble interleukin-6 receptor in patients with multiple myeloma. Cancer 1998;82:1860-1866.

26 Robak T, Wierzbowska A, Blasinska-Morawiec M, Korycka A, Blonski JZ: Serum levels of IL-6 type cytokines and soluble IL-6 receptors in active B-cell chronic lymphocytic leukemia and in cladribine induced remission. Mediators Inflamm 1999;8:277-286.
27 Soresi M, Giannitrapani L, D'Antona F, Florena AM, La Spada E, Terranova A, Cervello M, D'Alessandro N, Montalto G: Interleukin-6 and its soluble receptor in patients with liver cirrhosis and hepatocellular carcinoma. World J Gastroenterol 2006;12:2563-2568.

28 McKeown DJ, Brown DJ, Kelly A, Wallace AM, McMillan DC: The relationship between circulating concentrations of C-reactive protein, inflammatory cytokines and cytokine receptors in patients with non-small-cell lung cancer. Br J Cancer 2004;91: 1993-1995

29 Urbanska-Rys H, Wiersbowska A, Stepien H, Robak T: Relationship between circulating interleukin-10 (IL-10) with interleukin-6 (IL-6) type cytokines (IL-6, interleukin-11 (IL-11), oncostatin $\mathrm{M}(\mathrm{OSM})$ ) and soluble interleukin-6 (IL-6) receptor (sIL-6R) in patients with multiple myeloma. Eur Cytokine Netw 2000;11:443-451.

30 Barber MD, Fearon KC, Ross JA: Relationship of serum levels of interleukin-6, soluble interleukin-6 receptor and tumour necrosis factor receptors to the acute-phase protein response in advanced pancreatic cancer. Clin Sci (Lond) 1999;96:83-87.

31 Alberti L, Thomachot MC, Bachelot T, MenetrierCaux C, Puisieux I, Blay JY: IL-6 as an intracrine growth factor for renal carcinoma cell lines. Int $\mathrm{J}$ Cancer 2004;111:653-661.

32 Jablonska E, Pietruska Z: Changes in soluble IL-6 receptor and IL-6 production by polymorphonuclear cells and whole blood cells of breast cancer patients. Arch Immunol Ther Exp (Warsz) 1998;46:25-29.

33 Jablonska E: Changes in sIL-6R and sTNF-Rs release by PMNs and the serum levels in breast cancer patients at different stages of treatment. Cytokine 1998;10:540-543.

34 Jablonska E, Kiluk M, Markiewicz W, Piotrowski L, Grabowska Z, Jablonski J: TNF-alpha, IL-6 and their soluble receptor serum levels and secretion by neutrophils in cancer patients. Arch Immunol Ther Exp (Warsz) 2001;49:63-69.

35 Kovacs E: Investigation of interleukin-6 (IL-6), soluble IL-6 receptor (sIL-6R) and soluble gp130 (sgp130) in sera of cancer patients. Biomed Pharmacother 2001;55:391-396.

36 Singh A, Purohit A, Wang DY, Duncan LJ, Ghilchik MW, Reed MJ: IL-6sR: release from MCF-7 breast cancer cells and role in regulating peripheral oestrogen synthesis. J Endocrinol 1995; 147:R9-R12.

37 Oh JW, Revel M, Chebath J: A soluble interleukin 6 receptor isolated from conditioned medium of human breast cancer cells is encoded by a differentially spliced mRNA. Cytokine 1996;8:401-409.

38 Novick D, Shulman LM, Chen L, Revel M: Enhancement of interleukin 6 cytostatic effect on human breast carcinoma cells by soluble IL-6 receptor from urine and reversion by monoclonal antibody. Cytokine 1992;4:6-11. 